\title{
Exploring a narrative approach through music as a pastoral care means to human flourishing
}

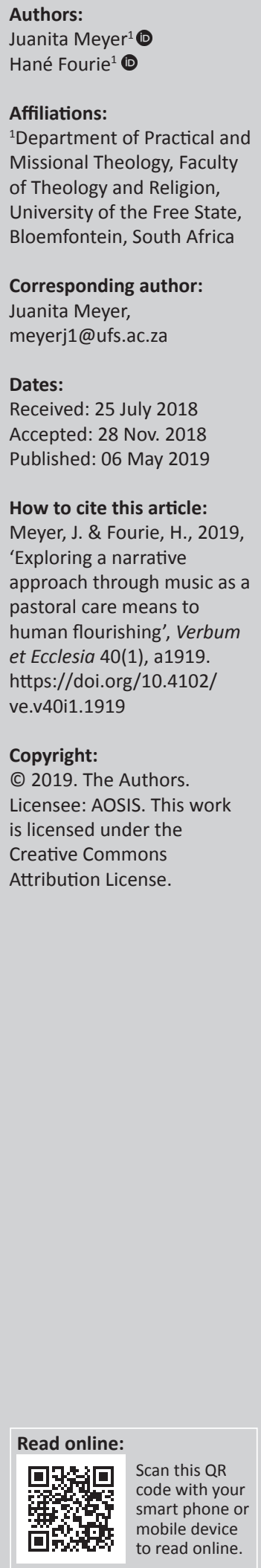

This article views Christian salvation through the lens of human flourishing and explores the unique ways in which music therapy - as a narrative approach to therapy - can assist society through the empowerment of the individual, to share in the kingdom of God, by actively participating in activities that will enhance people's sense of well-being and flourishing. Flourishing is not limited to the individual as an individual is formed and influenced by his or her community, society and related sociopolitical culture. To flourish is to restore the relationships between the self, others and God. To flourish is to have hope. This article aims to illustrate that the narrative approach to therapy can play a positive role in restoring relationships and creating hope. Similarly, this article argues for the ability of music (through narrative-music therapy) to lift people out of their problem-saturated narratives and assist them to create alternative narratives. Music is thus seen as a powerful tool that can be used as a method in the narrative approach to help individuals flourish in their current situations.

Intradisciplinary and/or interdisciplinary implications: This study is written primarily from a pastoral and practical theological perspective but engages on a secondary level with a narrative approach to research and therapy, which is a product of the theory of social constructionism. Social constructionism finds its home in the social sciences. From this engagement, practical theology and the narrative approach engage in a specific manner in dialoguing with the theories related to the study of music and its therapeutic benefits. The possible impact of this inter- and multidisciplinary engagement is the development of a specific kind of pastoral, music narrative therapeutic approach that provides possibilities of spiritual growth and healing to the seekers thereof.

Keywords: narrative; music therapy; pastoral care and counselling; life-giving or life-limiting theologies; narrative conversation.

\section{Introduction}

This article works from the assumption that every person not only has the desire to flourish, but also contains within themselves the means to actively partake in their own flourishing; in other words, every person has the desire to grow in the kingdom of God while still on earth.

The concept of 'human flourishing' has many diverse meanings as it has developed, and redeveloped through the ages, and through the understandings of different world views. Pennington (2015:1) is of the opinion that human flourishing can be understood universally, across various world views as 'the desire to live, and to live in peace, security, love, health and happiness'. As a philosophical and religious concept (e.g. Stoicism, Epicureanism, Islam, Christianity, Platonism, atheism, etc.), the concept varies from (Pennington 2015):

... being unaffected by the world, or being unaffected by false beliefs that there even is a god, to being your best person now by focusing on positive thinking, to embracing the suffering and difficulty God has for us, to not looking for human flourishing now but later, to living a life of serenity through achieving levels of greater consciousness, peace, and self-enlightenment, to becoming well-adjusted to our environment and relationships, to pursuing a life of practical wisdom and virtue. (p. 2)

Because this article is written from a Christian perspective of human flourishing, it becomes important to narrate the development of the concept of human flourishing during Western civilisation by referring to Augustine as the one figure with an immense influence on Western thought. In his Trinitarian understanding of life and the world, Augustine relates human flourishing and therefore happiness to humans centring their lives on God. Augustine takes this relation further in stating that the 'double love for God and neighbour' (Pennington 2015:3) is indeed the ultimacy of the good. It is clear therefore that since the beginning of civilisation, 
flourishing, happiness and the supreme good is directly related to fellowship (mutatis mutandis), and is extended into the following 1400 years when it reaches climax in the philosophy of Aquinas (cf. Pennington 2015:3).

As such, many Christians are of the opinion that flourishing is not necessarily measured by financial or material wellbeing, but more so by the spiritual and emotional well-being of each person within his or her specific local context - even though this context might be fraught with material and psychosocial shortcomings. Flourishing is therefore intimately linked with the concepts of 'thriving', 'health' and 'well-being', which takes place in relation to God and fellow human beings.

Anton Boisen (1876-1965), the founder of the clinical pastoral educational movement (cf. www.boisenbooks.com), links health to religious ideals, which are according to him social in essence, as seen through the emphasis on community (cf. McClure 2010:183). According to this perspective, many pastoral theologians link health to a person's social circumstances (e.g. Carol Weis, Anton Boisen and Seward Hiltner). In an attempt to reduce individualism in pastoral care, counselling and theology, Miller Mc-Lemore (1996) broadened Gerkin's (1990) metaphor of the 'living human document' to a 'living human web' as the focus of pastoral attention. This adapted metaphor emphasises the importance of the individual to be part of a community and the significant role that relationships play in an individual's health and ability to flourish (cf. McClure 2010:184-185).

In reaction to the proposal of pastoral care being directed not only to the community but also to the sociopolitical culture of a specific context in which an individual finds himself or herself, McClure (2010:187) proposes a synergistic perspective to human flourishing. A synergistic understanding of relationships is in essence a theological anthropology in which developing persons can be viewed as important agents in their own development and change that takes place in the world around them. This perspective proposes that human development takes place within relation - and in relations, a person can experience either inclusion or exclusion. Experiences of either being included or excluded, 'deeply effect persons' physical, emotional and spiritual development by affording and/or limiting opportunity and possibility, access to resources, and setting the context of life experiences' (McClure 2010:187). In turn, social experiences directly influence a person's ability to flourish.

Reference to co-creative performance denotes the 'constructive nature inherent in narratives' which, in turn, reflects the dominant discourses held onto by a society or community. Accordingly, Loubser and Muller (2011) state:

People construct stories about themselves and their experiences, as well as the meaning of these experiences for them in a specific context, influenced by various traditions. Thus when a narrative is told, multiple dimensions of influence are unveiled. (p. 5)

Although life stories and associated meanings are socially constructed, the relevance and significance of an individual's life stories are not negated. This life story serves as a resource centre for the construction of an individual identity, which is used, in turn, to understand personal and social experiences and events (cf. Loubser \& Muller 2011:5), such as to co-construct new narratives related to what it means to flourish and thrive, both as an individual and a community or society.

The remainder of this article emphasises the important role that narrative therapy can play in a person's well-being and the pursuit of flourishing, and the contribution made by music as a method in the practice of narrative therapy in assisting clients to flourish and thrive in their specific contexts.

The narrative approach to pastoral care and therapy is at its very essence, postmodern, which opens the possibility of dialogue from a variety of voices or disciplines related to human flourishing. Therefore, although this article focuses on the contribution of a narrative approach to pastoral care and therapy related to human flourishing, the voices of disciplines specifically related to music studies will also be put forth. The method and structure of this article are based on Müller's (1996) narrative model or conversation agenda.

\section{The narrative approach to pastoral care and therapy}

White and Epston (1990:69) state that when people tell stories about their lives, they attach meaning to their experiences. Through this approach, the client - and not the therapist remains the expert of his or her own life. Instead the therapist journeys with the client on his or her explorative expedition. According to this approach, the role of the therapist is to keep the narrative alive during the sessions by means of asking 'curious questions'. It is important to note that this is an approach which creates space for each client's unique therapeutic experience. There is no step-by-step 'recipe' used by the narrative approach; although core concepts and processes are utilised. In this specific article, an argument is made for music or musical activities as a method to keep these narratives or stories alive in the sessions - especially in cases where the client is hesitant to answer these 'curious questions'.

According to Ganzevoort's (2012:216) discourse, knowledge and action are perceived as social constructions and understandings of the world and ourselves with the aim of making sense of our reality, while appealing to others who form the 'audience' of the stories. When a life story or narrative is told, or when the stories of a religious tradition in the liturgy are re-enacted and re-told, people are actively deciding what to include and how to structure the story in such a way that it will appeal to the audience. Therefore, a narrative approach considers relationships: the relation of the story with that which is specified (tradition, reality and the facts in one's life course) and the relation of the story with those for whom the story is told.

Raglio (2010:2-3) is of the opinion that similar to other therapeutic approaches, it is important in music therapy to define the 'therapeutic setting' in order to promote therapeutic 
action and change. The aim of a music therapist is therefore to establish a relationship with the client and to establish the echoing-musical element as the means through which this relationship is created. The therapeutic setting of music therapy is thereby combined with the setting of a narrative approach to therapy in building professional counsellorclient relationships.

In this article, music therapy is understood as the use of music or musical activities (songs with certain rhythms, with or without lyrics) during narrative pastoral sessions to assist with the facilitation of a person's self-discovery process. StevensonMoessner (2008:56) regards theology as the music of religious research, available to all people, and not only the theologian. God has created us to be living instruments who are capable of creativity. Maritz and Dreyer (2002:1272) suggest that poetry, metaphors, symbols, art and music bring about a meeting between man and God where techniques and words are sometimes not enough. Accordingly, this article will elaborate on how music and musical activities can be used as a method in Müller's (1996) narrative conversation model or agenda.

According to this approach, the narrative theory is grounded in the human story which only makes sense when it is told as a unity. The narrative that grows out of human experience entails a tension between the modes of the past, present and future (cf. Müller 1996:102). The structure of the narrative conversation agenda consists of the following five stories (Müller 1996):

(1) a story of distress

(2) a story with a story (past)

(3) a darkened future story

(4) restructuring of the past story

(5) reconstruction: the imagination of a new story (p. 102).

\section{A story of distress}

From a postmodernist point of view, Doehring (2015:9) states that caregivers should listen for the lived theology in the narratives of clients. Many lived theologies attain power through emotions and are held together by these emotions. In some cases, strong emotions such as fear, shame, guilt and/or anger are associated with these theologies. Noteworthy is that experiences of loss, violence and the problematic handling of emotional dynamics that create lived theologies can be either life-giving or life-limiting.

Doehring (2015:4-5) uses the term 'lived theology' to define the emotionally charged group of beliefs, values and practices used to attribute meaning to spiritual and emotional experiences. These lived theologies are not permanent or unitary but are always shifting, depending on invigorating sets of emotions. Doehring (2015:4-5) states that the term 'lived theology' points to the personified, emotionally charged internal logic of beliefs, practices and values that establishes this lived theology.

This article views this focus on 'lived theology' as a natural addition to a narrative approach to pastoral care, as the manner in which people embody beliefs and values in daily practices and are illustrated by the construction and telling of narratives.

It is assumed therefore that an individual cannot flourish when experiencing a certain degree of distress. Müller (1996:107) illustrates this idea through the telling of a story of a Roman person who showed his shoes to a crowd. He told the crowd that they can see his expensive shoes, but they cannot see where the shoes hurt him. Müller (1996:107) used this illustration to reinforce the statement that people seek help from a pastor or pastoral therapist because their 'shoes' are hurting them somewhere. Similarly, some people can vaguely indicate where it hurts, but most people just experience a general feeling of discomfort.

According to Müller (1996:107), the pastor's or therapist's greatest task is to listen to and interpret people's stories. The stories people tell are already an interpretation of their experiences. An individual's or family's past and future experience collapse into the present. This 'collapse into the present' means that emotions of intimacy, openness, injuries, confusion and futility come to the surface. This is expressed as the distress of the problem which the individual or family has to deal with.

Counsellors can therefore listen for underlying emotive expressions in clients' narratives, which might be associated with a group of beliefs, values and practices that attribute meaning to their spiritual or emotional experiences. As stated by Doehring (2015):

Emotions like tenderness and affection might well connect values like belonging, beliefs in God's incarnational compassion with all humanity, and coping through social support. In contrast, emotions like fear could hold together values like selfreliance, beliefs that harm will come when one is not vigilant, and coping through addictive substances. (p. 5)

Perry (2008:135) furthermore postulates that life narratives capture the theological occurrence of representation. God reveals himself through the narratives of people, the narratives from the Bible and the narrative of Jesus. In Jesus' story, humanity is brought into God's narrative. There is a mutual participation from God and humanity - God presents humanity with a story which they may share, and in this sharing, a new community arises.

To overcome losses and celebrate gains are regular themes in the narratives of individuals, families and organisations that transition through the life cycle. One such underlying theme which might appear in an individual's narrative is violence. The problematic handling of stress through, for example, addiction can also become a recurring theme in many people's narratives. Similarly, the theme of loss is a major cause of suffering in an individual's or community's life, as sadness and suffering are experienced both personally and relationally.

The pastoral caregiver should therefore connect a care seeker's experienced emotions with his or her values, beliefs 
and management practice, instead of only assisting the care seeker to understand the emotional dynamics of mourning, trauma and addiction. This, in turn, creates awareness of both the individual's and communities' active construction of either life-limiting or life-giving theologies (cf. Doehring 2015:10-11). An alternative perspective on emotions creates a postmodern shift by moving away from individualism to a more social therapeutic approach, in ultimately creating a therapeutic society (Doehring 2015:11).

\section{A story with a story (past)}

Müller (1996:111) makes the statement that every person has a story. This 'story' usually refers to the past and forms part of an individual's identity and as such can be seen as the basis narrative with which the therapist can work. The memories and interpretation of past narratives provide the material with which the individual's future story is built. A person does not have to remember everything that happened in the past; however, to deny certain things that happened in the past consequently leads to limited 'material' available with to build the future story which (Müller 1996:111):

Past, present and future are for the human mind and heart the 'three dimensions or direction into which the human sense of time extends and which in their togetherness constitute the present moment. (Lester 1995:14)

The above insight from Lester (1995:14) forms the philosophical basis for the possibility of renewal and change without which narrative therapy would be meaningless and inadequate. The human being is a self-conscious being, aware of what has happened - in anticipation of what is coming and can therefore develop, change, heal and become liberated. As beings with a self-transmitting spirit, we can remember what happened and at the same time anticipate what is to come. Both these aspects, the memory and the anticipation, influence the way in which we live in the present (Müller 1996:113).

Müller (1996:114) reiterates that reality is structured through the telling and retelling of stories. Therefore, the context of the past can influence a person's current actions. Without making retrieving of the past prerequisite to change (as in Freudian psychology), it should nevertheless be emphasised that the narrative of the past should be thoroughly dealt with for a therapeutic process to be successful. The narrative approach stresses the 're-living' of the past during the present situation, and not necessarily the 're-calling' of a deceased past, as with Freudian psychology. The result is that memory is approached as a constructive system and not as a recycling system (Müller 1996:114).

Perry (2008:140) explains the role of the therapeutic listener as someone who adjusts the manner in which sufferers are involved with stories of constant suffering, especially through their ways of communicating this narrative. A new framework of interpretation of their suffering is achieved through the creation of a new voice and alters the way in which the client addresses a memory. The expansion of the life story by outlining the story is the result of the residue of thinking, speaking and reasoning about events of the past. If the former is considered, the conclusion can be made that communication assists in the narration and delineation of life events, which, in turn, is used as a frame of reference in interpreting these and future events.

\section{A darkened future story}

Lester (1995:20) says that people are unaware of the amount of time they spend on future planning (cf. Müller 1996:115). For Lester (1995), the future is not only about future events, it is already alive in expectations and anxieties, in planning and design, and can therefore be seen as an integral part of the present. Accordingly, this 'disturbed' future perspective is the primary motivation for meaningful change. Müller (1996:116) states that people consult therapists or pastors primarily because they have lost perspective and are tired of only seeing the barrier. Müller is of the opinion that when people are helped to regain perspective, their experience of the present will change.

Ballaban (2014:3) uses the idea of 'metanarratives' in regaining perspective. He defines metanarratives as the bigger, implicit set of expectations about the way things really are, or should be in the world, which are then preserved by certain stories embraced by individual faiths, peoples, nations or cultures and are valued as 'their' story. These metanarratives often include stories with traumatic events, such as injury, death, loss and war. Biblical narratives (such as the story of Joseph in Gen 37, sold into slavery) often contain traumatic incidences, which are often emotionally or conceptually difficult for readers to grasp. Ballaban (2014:4-7) suggests utilising these stories as powerful metaphors during counselling, as biblical texts have been used for many years as a therapeutic tool. Recent studies have shown that religion and religious experiences are important sources of relief following traumatic experiences, and as a result, Ballaban places it as the second most common coping strategy, after talking to others about the event. In a similar fashion, Kwok (2016:209) argues that the gospel should be incorporated into the counselling process by virtue of its proclamation that God's unconditional promises can renew individual-selves. The gospel gives an alternative life narrative that consists of the possibility of empowerment, liberation, joy and hope, thereby indicating that God is the giver of hope which motivates the development of an alternative story.

\section{Restructuring of the past}

According to Müller (1996:117), the strengthening of identity is facilitated by the positive restructuring of the life story. The story gets restructured when new meanings are allocated to events. Thus, to improve and refine interpretation capabilities is to become more human. By guiding people in interpreting what has happened to them, what is still happening to them and what may still happen through the telling of a meaningful story is to help 
people move to a higher level of humanity. To come to terms is to come to understand (Müller 1996:117-118):

Forgetting the narratives of self, family and community is inhuman because our accumulated history of suffering and happiness is then gone and forgotten. (Webb-Mitchell 1995:223)

Müller (1996:118) is of the opinion that the past may never be forgotten, or else there would be no lens through which the future can be viewed. Muller states that in order to forget healthily, it is necessary to remember well; otherwise, what is forgotten becomes nothing more than unhealthy displacement. He compares the reinterpreted past story with 'backtracking' and 'looping' and states that 'backtracking' is comparable with chronicle writing which is defined as the simple sum of events that compose a person's history. He states that a reinterpretation entails more than this. In turn, Estés (1994:59) describes 'looping' as tracing one's footsteps in gaining an understanding of one's journey. Change in the present and future can only take place when stories of the past are reinterpreted, and the past can be interpreted only with the use of categories - a horizon or tradition that helps you interpret the past meaningfully. It is this horizon that provides the symbols, myths and other categories for interpretation. No person is without such a horizon, and every person is located within a tradition that is already utilised as a frame of reference in multiple processes of interpretation (cf. Müller 1996:119-121).

McClure (2010) argues that a person cannot be fully understood if the sociopolitical context is not considered and that an individual should be seen and treated in his or her holistic being. Müller (1996:121) explains that tradition is already an interpretation of symbols and myths, and that the pastorate must work towards a reinterpretation of this tradition, which entails a restructuring of the horizon in the reinterpretation of the past. An individual's biography (life history) should not be seen as the sum of all the experienced events but it should rather be viewed as a personal identity an interpretation of the past to create order from the unstructured past. In turn, the restructuring activity should not be viewed as a superficial retelling, but rather a reorientation in terms of rediscovered values from which a new story of the former story becomes possible.

The concept of 'reformulation' and 'restructuring' does not mean that an individual's story should be repeated in a positive light, but that the experienced 'stuckness' is reformulated as the first point of departure in true change. To be able to reinterpret and ultimately restructure a story language, reformulation skills should be utilised. The creative use of language involves attaching different meanings to the same experiences, which will ultimately lead to the restructuring and reconstruction of stories within the therapeutic environment (cf. Müller 1996:123, 129).

Anderson and Goolishian (1988:371) confirm the use of language within the therapeutic environment as the therapeutic system develops parallel to the development of a language system. The social unit utilised in therapy is in actual fact a language system which is distinguished from other types of systems by a so-called 'in-language' event. Therefore, it becomes imperative that the therapist communicates in the client's language, as language is the metaphor in which a client expresses experiences. The words, language and associated meanings are therefore an interpretation of life events. The therapist must be a respectful listener who is not in a hurry to understand (cf. Müller 1996:130-131).

\section{Reconstruction: The imagination of a new story}

Healing is described as being affected when one of three things takes place: a sense of wholeness in the face of - or even because of - pain or suffering; a heightened ability to endure pain or suffering; or/and finding purpose and meaning in pain or suffering. A conversation can thus accordingly become a healing process (Miller 2016:26-27).

Narrative therapy can similarly assist an individual to attain personal transformation by altering their perception of their life stories (Kwok 2016:203). Müller (1996:132) postulates that to restructure is to reform perceptions and to change cognitive maps according to these events. This, however, does not happen easily. Lester (1995:44) argues that fracture, fear, anxiety, loss, divorce, emotional pain and suffering relate to future stories that are disintegrating. In light of this, significant reformulation must be understood in terms of the future story and not only in terms of a better presentation of the past story. Pain is not only the result of a story that did not succeed in the past but probably the inability to construct a meaningful future story from it (Müller 1996:133).

Revelation 1:8 states: 'I am the Alpha and the Omega', says the Lord God, 'who is, and who was, and who is to come, the Almighty'. Müller (1996:133-134) refers to this text in explaining that God's future is not described in terms of a continued existence, but rather in terms of a coming-from-the-future; not a move towards the future but a move from the future to the present. Faith then is to have the awareness that God is coming to you from the future. A reconstruction of the vision of the future is a powerful means of change in the present as it allows people to become motivated, excited and maintain a sense of purpose. Images (imagination) of what will be in the future are projected from past and present experiences. Accordingly, people orientate themselves to the future by formulating stories regarding what may happen in the future. These constructed stories become roadmaps for our life journeys (Müller 1996:135).

Müller (1996:137-138) believes that the imagination and imagery of a story are closely related. Imagination is not possible in the absence of cognitive images or talking in metaphors about one's life. In turn, imagination does not indicate a closing of the past in the sense of forgetting. Rather, the relevance of the negative of the past and the positive of the future must be rediscovered through 'finalisation' and 'reorientation'. The narrative approach to therapy as developed by White (1989:5) provides some suggestions in 
attaining 'finalisation' and 'reorientation' during the development of an alternative narrative. One such suggestion is the use of 'externalisation' whereby problems are objectified and personalised. Accordingly, the problem becomes a separate entity and as such is neutralised, thereby creating opportunities in the construction of new stories. The externalisation of a problem also allows an individual to shed dominant stories that constantly shape their lives and relationships. This makes it possible to assign other meanings to events (Müller 1996:165-166).

In externalising the problem, it is suggested that the problem is given a name. By searching together for a name in describing the problem, the therapist and the client partner together against the problem. Secondly, the problem must be personalised by attributing all kinds of negative intentions and tactics to it. Metaphors and images can be utilised to assist with this process. Thirdly, the ways in which the problem is destructive, dominant and discouraging must be investigated as the problem is seen to effect, invite, tell, try and convince (cf. Müller 1996:167).

By facilitating the externalisation of a problem, instances of control over the problem can be searched for and identified. These instances are called 'unique outcomes' and assist in the repositioning of the client towards the problem. This new position opens possibilities for the rich description of experiences and can result in the creation of new possibilities and understandings that can break ties with all the instances of problem-saturated explanations contained within narratives. In essence, this approach to therapy empowers individuals to escape their stereotyped narrative reality (cf. Kwok 2016:203-204). By combining the narrative approach to therapy with pastoral care, faith communities can nurture and challenge the brokenness of this world by reconciling people with a life filled with narratives of God's grace, healing and hope as visible through the Christian stories about God's action with people throughout history (cf. Smit 2015:4).

\section{The role of music as a narrative method in Müller's conversation model}

As stated at the beginning of this article, it argues for the use of music as a narrative method as it is used in Müller's (1996) conversation agenda or model.

\section{The story of distress}

The researcher views Doehring's (2015) description of lifegiving theologies as a theology that gives hope. Aldridge (1995:103) links the promotion of hope to the creative use of music as the central emphasis of spirituality as it will help an individual to achieve a new consciousness by surpassing the moment. The concept of hope therefore includes the expectancy of a leap forward. It is then argued that this leap can be made through the creative act of music as music is an inseparable part of a person's experience of reality (cf. Maritz \& Dreyer 2002:1277). Aldridge (1995:104) confirms the reality of music in people's lives in stating that a new awareness is created by surpassing the moment of suffering through the concrete enactment of music. Because feelings are reflected through the making or singing of music (cf. Aldridge [1995:104]), it is suggested that a client can be offered the opportunity to identify a song which might reflect how they feel at that moment during a therapy session. This creates the possibility of discussing why the song reflects the feelings, or the narrative of the client and can be the start of a meaningful conversation.

\section{The story with a story}

Maritz and Dreyer (2002:1272) postulate that music offers the opportunity for 'ruler-free' communication. This means that the therapist and client are equal partners in search of alternative stories. Music therapist and researcher, Alfredo Raglio (2010:1-2), states that when musical activities are suggested to people with dementia, the main objective is to create a state of socialisation and well-being through the use of various music suggestions (e.g. rhythmic use of singing, movement associated with music, instruments, etc.). He adds that there are several possible experiences of listening to music: Music is often reminiscent, as it stimulates memories through moments of expression. Music can also be used to facilitate the structured moments of the day or surroundings. It is also believed that the listening to music (classical, favourite music, etc.) can reduce behavioural disorders and enhance socialisation or an individual's mood (cf. Raglio 2010:2).

According to Raglio (2010:3), a sound-music element has the ability to create more complete and available material in the brain, both in terms of production and listening. Maritz and Dreyer (2002:1283) confirm that music can - through association - recall past experiences. They explain this phenomenon by classifying the contents of music as being within a certain structure or form - this helps the classifying brain to associate music with certain events. Music can thus structure experiences by capturing the music's form and content in the subconscious.

From the above, it is then deduced that musical activities can be useful tools in taking people back to certain events in their lives. Musical activities can help recall certain memories that may have been unconsciously suppressed by an individual. Without these memories being recalled, real healing and flourishing are impossible (cf. Muller 1996:118).

\section{The 'darkened future story'}

The unpredictability of the future is often represented by music, and especially through the silence in music. According to Perry (2008:141), another element of hearing narratives or stories is listening for silent stories. Silence, just as audible music, can be recognised as a type of language, where the rhythms of silences and the gaps between delicate words should be listened for in hearing what a client wants to say. 
Twentieth-century composers, like John Cage (1912-1992), also emphasised the importance of silence in music (see Cage 1961). Maritz and Dreyer (2002:1284) make the connection between music and pastoral care through the silence in the music of the Israelites when referring specifically to the narrative contained in Psalm 137. According to this narrative, the captivated Israelites hung their harps as an expression of their grief. From these statements, it is concluded that only when music is used in its full meaning, consistency and functionality, the true meaning and value of silence and stillness can be understood. Stillness and silence are therefore critical in the development of an alternative narrative for the future.

The pastoral narrative therapy suggested in this article aims to use the hope contained within music (rhythm and lyrics) as the ignition of expectation for the future, by re-joining music and memories from the past with the often (hopeless) reality of the present (cf. Maritz \& Dreyer 2002:1285). The 1964 musical, Fiddler on the Roof, provides an example, where Tevye the Dairyman asks God in the form of song if it would hurt anybody if he was a rich man. This hopeful song helps him to cope with the reality of his present situation.

The metaphors of 'backtracking' and 'looping' used by Müller (1996) suggest that the use of music can make a valuable contribution to the processes of 'restructuring the past story'. The term 'composition' of events is linked with the musical connotation of composing a song. According to Maritz and Dreyer (2002:1282-1283), music represents emotional process well, because music, like reality, is always in constant motion. Likewise, music can awaken personal feelings in the individual, to which he or she has become numb. Music can lead the person to introspection which is necessary for personal growth and actualisation. Music can through association - recall immediate experiences from the past and therefore possess the ability to highlight the listener to awareness above their immediate reality.

\section{The imagination of a new story}

In the famous and beautiful lyric of Tim Rice's song, 'Any dream will do', and in his and Andrew Lloyd Webber's production, Joseph and the Amazing Technicolor Dream Coat, there are striking expressions of how a dream relates with the past and the future. To dream is not enough (Müller 1996:136). Imagination is indeed necessary, yes, but it should also be translated into workable strategies. In a demonstration of the pastoral wisdom entailed within the above production, the latter song in this same production Go, go, go Joseph states:

Hang on now Joseph you'll make it someday

Sha la la, Joseph you're doing fine

You and your dreamcoat ahead of your time

Without the wisdom of these three rules, no pastoral intervention can be complete. Müller (1996:136) posits three rules inherent in these three lines, that point to the practical wisdom needed by all pastoral care interventions: encouragement (Hang on!), strengthening (You're doing fine!) and reinterpretation of the story (... ahead of your time!). At the centre of this narrative is the 'dream coat'; encouragement, positive reinforcement and reinterpretation can only be meaningful when created around the imagination of the future.

The use of metaphors in the unfolding of a new story is extremely important and as such, this article argues for the use of music to help people think in metaphors and assist in developing a new future story. Music and its lyrics as a creative form of language can assist people to identify and describe feelings, memories and wishes. Similarly, Maritz and Dreyer (2002:1268) state that the use of symbols, metaphors, images, rituals, music and art can guide the postmodern person to healing as it becomes a God-given medium through which creativity in relation to God and each other can be embodied. Music, for Maritz and Dreyer (2002:1268), is, in essence, an anthropological expression which can lead man to a 'participative consciousness' with man himself, others and nature, and can be the vehicle through which change and understanding is facilitated. Through imagination and metaphors, contradictions are equally integrated into a new story. Müller (1996:140) illustrates how contradictions can be integrated into a narrative, with the use of Cockburn's song (cf. Middleton \& Walsh 1993:21) where 'military dictatorship' and 'hope' are reflected together with the use of the metaphor of 'grass piercing through hard cement' (Middleton \& Walsh 1993):

I've got a dream and I'm not alone, darkness dead and gone All the people are marching home, kissing the rush of dawn Santiago sunrise, see them marching home

See them rising like grass through cement, in the Santiago dawn. (p. 21)

This section has illustrated the ability of music to 'transport' people away from their current situation towards a preferred reality. It is therefore argued that music and musical activities can be used within the therapeutic environment to assist clients in externalising their problems, thereby creating distance between the person and the problem-saturated story. This distance, in turn, creates perspective and, thereby, the possibility of healing.

\section{Implications}

A narrative approach to therapy addresses not only challenging individual stories, but also intimidating, discriminative and prejudiced strands in overarching communal stories. How clients tell and interpret their stories have the potential to reveal something about the divine and to strengthen their union with God and God's people. Through the narrative approach, people are empowered to regain control over their lives by journeying together with the pastoral therapist, or caregiver in discovery of those stories that shed light on a different (non-dominant) interpretation of their past and present stories.

This article has argued for the use of music and musical activities as a narrative facilitative tool in creating 
opportunities for ruler-free communication in which memories and associated emotions can be expressed and interpreted, so as to create a more complete, liberating and satisfactory life story or narrative. With the use of Müller's (1996) conversation agenda or model, the article aimed at narrating possibilities inherent in music and musical activities at each point of the agenda, in constructing an alternative narrative. It has been shown that music and musical activities can be used during the 'story of distress', in starting a meaningful conversation about past narratives and associated emotions. During the 'story with a story', musical activities can be used to 'transport' the client back to certain events and associated emotions which the client might have suppressed. Similarly, the silence entailed within music and musical activities can be utilised in unravelling the 'darkened future story' (or unknown future story), as the silence in music is composed for a certain reason and to create a certain effect.

During the 'restructuring of the past story', music and musical activities have the possibility of creating moments of introspection necessary for personal growth and actualisation. During the 'story of reconstruction', music and musical activities can be utilised in the externalisation of problemsaturated stories, thereby creating possibilities of hope. Moreover, music has the ability to encourage a person to pursue this new-found hope and dreams in the creation of an alternative story. It is then concluded that music and musical activities can be utilised during narrative pastoral therapy to develop stories of hope and flourishing. To flourish is to have hope and to restore the relationship between self, others and God. Music is the narrative of heart and soul and contains the possibility of transporting us to a world where the spirit meets the embodiment of God's love and grace.

\section{Acknowledgements Competing interests}

The authors declare that they have no financial or personal relationships that may have inappropriately influenced them in writing this article.

\section{Authors' contributions}

This article is based on the research conducted by H.F. in submission of an article for the fulfilment of the degree of MDiv in Theology. Therefore, H.F. wrote the article and the supervisor (J.M.) edited the article and added some theoretical sections for its completion.

\section{References}

Aldridge, D., 1995, 'Spirituality, hope and music therapy in palliative care', The Arts in Psychotherapy 22(2), 103-109. ATLA Religion Database with ATLASerials, EBSCOhost.

Anderson, H. \& Goolishian, H., 1998, 'Human systems as linguistic systems: Preliminary and evolving ideas about the implications for clinical theory', Family Process 27(4), 371-393 (1988:371)

Ballaban, S., 2014, 'The use of traumatic biblical narratives in spiritual recovery from trauma: Theory and case study', The Journal of Pastoral Care \& Counselling 68(4), 1-11. ATLA Religion Database with ATLASerials, EBSCOhost.

Cage, J., 1961, Silence; lectures and writings, Wesleyan UP, Middletown, CO.

Doehring, C., 2015, 'Narrative themes of loss, violence and coping', in C. Doehring, (ed.), The practice of pastoral care: Revised and expanded edition, pp. 117-154, WJK Press, KY.

Estés, C.P., 1994, Women who run with the wolves, Random House, Bergvelei, SA

Ganzevoort, R.R., 2012, 'Narrative approaches', in B.J. Miller-McLemore (ed.), The Wiley-Blackwell companion to practical theology, pp. 214-223, Blackwell Publishing Limited, Oxford.

Gerkin, C.V., 1990, 'Interpretation and hermeneutics, pastoral', in J. Hunter (ed.), Dictionary of pastoral care and counseling, Rodney, pp. 591-593, Abingdon, Nashville, TN.

Kwok, W., 2016, 'Narrative therapy, theology, and relational openness: Reconstructing the connection between postmodern therapy and traditional theology', Journal of Psychology \& Theology 44(3), 201-212. ATLA Religion Database with ATLASerials, EBSCOhost.

Lester, A.D., 1995, Hope in pastoral care and counselling, Westminster John Knox Press, Louisville, KY.

Loubser, J. \& Muller, J.C., 2011, 'The use of metaphors in narrative research in exploring and describing experiences of adolescent male orphans affected by HIV and AIDS', HTS Teologiese Studies/Theological Studies 67(2), Art. \#1009, 9 pages. https://doi.org/10.4102/hts.v67i2.1009

Maritz, J.F. \& Dreyer, T.F.J., 2002, "n Ondersoek na die aanwending van musiek as hulpmiddel in pastorale terapie binne 'n gespreksmodel', HTS Teologiese Studies/ Theological Studies 58(3), 1265-1285. https://doi.org/10.4102/hts.v58i3.595

McClure, B.J., 2010, Moving beyond individualism in pastoral care and counselling, Cascade Books, Oregon.

Middleton, J.R. \& Walsh, B.J., 1993, 'Theology at the rim of a broken wheel: Bruce Cockburn and Christian faith in a postmodern world', Grail 9(2), 15-39.

Miller, A.J., 2016, 'The spiritual staircase: A narrative approach to pastoral conversation', The Journal of Pastoral Care \& Counselling 70(1), 26-33. ATLA Religion Database with ATLASerials, EBSCOhost.

Miller-McLemore, B.J., 1996, 'The living human web: Pastoral theology at the turn of the century', in J. Stevenson-Moessner (ed.), Through the eyes of women: Insights for pastoral care, pp. 9-26, Westminster John Knox, Philadelphia, PA.

Müller, J., 1996, Om tot verhaal te kom: Pastorale Gesinsterapie, RGN Uitgewery, Pretoria.

Pennington, T.P., 2015, 'A biblical theology of human flourishing', in Institute for faith, work and economics, viewed 20 November 2018, from https://tifwe.org/ resource/a-biblical-theology-of-human-flourishing-2/

Perry, A., 2008, 'Listening, narrative, and atonement', Wesleyan Theological Journa 43(1), 133-145. ATLA Religion Database with ATLASerials, EBSCOhost.

Raglio, A., 2010, 'Music therapy in dementia', Non-Pharmacological Therapies in Dementia 1(1), 1-14. ATLA Religion Database with ATLASerials, EBSCOhost, viewed 05 June 2018.

Smit, D., 2015, 'Reading the Bible through the ages? Historical and hermeneutical perspectives', Stellenbosch Theological Journal/Teologiese Joernaal 1(2).

Stevenson-Moessner, J., 2008, Prelude to practical theology: Variations on theory and practice, Abingdon Press, Nashville, TN.

Webb-Mitchell, B., 1995, 'The importance of stories in the act of caring', Pastoral Psychology 43(3), 215-225. https://doi.org/10.1007/BF02253788

White, M., 1988/89, The externalizing of the problem and the re-authoring of lives and relationships, Dulwich Centre Newsletter, Summer (special edition), Republished 1989 in White, M.: Selected papers (chapter 1), pp. 5-28, Dulwich Centre Publications, Adelaide.

White, M. \& Epston, M., 1990, Narrative means to therapeutic ends, Norton, New York. 